Ks. Jan W. ŻELAZNY*

\title{
BIBLIJNE UZASADNIENIE PRYMATU BISKUPA ORIENTU NA PODSTAWIE LISTÓW TYMOTEUSZA I, PATRIARCHY BAGDADU
}

1. Egzegeza orientalna. Nie ma za wiele opracowań dotyczących tego zagadnienia. Jednym z nich jest zapis kursu, jaki w Instytucie Biblijnym w Jerozolimie miał Sabino Chiala ${ }^{1}$. On sam, jak pisze we wstępie, opierał się na pracach Sebastiana Brocka ${ }^{2}$ oraz Lucasa van Rompay'a ${ }^{3}$. Zwraca uwagę na trzy główne zagadnienia konieczne przy uwzględnieniu specyfiki egzegezy orientalnej. Pierwszym z nich jest starożytność tradycji syriackiej, jej semickiej mentalności oraz szczególnej relacji do Biblii i tradycji żydowskiej. Drugim faktorem istotnym w dalszej analizie jest język przekazu - semicki, o bogatej strukturze i specyficznej formie. Trzecim jest kwestia podziału na różne wspólnoty w zależności od stosunku do uchwał soboru w Chalcedonie. Nie bez powodu mówi się o tych Kościołach, że są to żywe skamienieliny sporów chrystologicznych. Choć ich chrystologia zarówno wtedy jak i dziś jest bardzo bliska (niektórzy badacze mówią często o różnicach formalnych a nie rzeczywistych), tym niemniej podziały te skutkowały odrzuceniem niektórych założeń przyjmowanych przez drugą stronę. Formalnie rzecz biorąc negowano spuściznę przeciwnej wspólnoty. Stąd niektórzy autorzy są nominalnie nieobecni w konkretnych konfesjach, choć nie można tego powiedzieć o ich myśli. W tym względzie okazuje się, że znani - zarówno przez zwolenników jak i przeciwników - tacy Ojcowie Kościoła, jak Teodor z Mopsuestii, Jan Chryzostom, Nestoriusz czy Cyryl Aleksandryjski, wywarli znaczący wpływ na późniejsze dzieje egzegezy w Kościołach o tradycji syryjskiej.

\footnotetext{
* Ks. dr hab. Jan W. Żelazny, prof. UPJPII - kierownik Katedry Patrologii na Wydziale Teologicznym Uniwersytetu Papieskiego Jana Pawła II w Krakowie; e-mail: jan.zelazny@upjp2.edu.pl.

${ }^{1}$ Por. S. Chiala, La perla dai molti riflessi, Qiqajon 2014.

${ }^{2}$ Por. S. Brock, Una fontana inesauribile. La Bibbia nella tradizione siriaca, Roma 2008.

${ }^{3}$ Por. L. van Rompay, The Christian Syriac Tradition of Interpretation, w: Hebrew Bible Old Testament. The History of Its Interpretation, ed. M. Saebo, vol. 1: From the Beginnings to the Middle Ages (Until 1300), part 1: Antiquity, Güttingen 1996, 612-641; tenże, Development of Biblical Interpretation in The Syrian Churches of the Middle Ages, w: Hebrew Bible Old Testament. The History of Its Interpretation, ed. M. Saebo, vol. 1: From the Beginnings to the Middle Ages (Until 1300), part 2: The Middle Ages, Güttingen 2000, 559-577
} 
W niniejszym opracowaniu zajmę się egzegezą, jaką podejmuje Tymoteusz I, patriarcha Kościoła w Koke (Seleucja-Ktezyfont), odnosząc się do biblijnych podstaw prymatu w Kościele, jaki jego zdaniem przysługuje patriarchom Wschodu. Był zwierzchnikiem Asyryjskiego Kościoła Wschodu, pełnił swój urząd przez 43 lata (780-823) i za jego czasów de facto przeniesiono siedzibę do stolicy państwa kalifów, do Bagdadu ${ }^{4}$. Jest więc przedstawicielem egzegezy orientalnej, wschodniosyryjskiej. Jako przykład egzegezy posłuży analiza fragmentów biblijnych, jakie przytoczył patriarcha nie tylko dla poparcia tezy o swoim prymacie w Kościele powszechnym, ale także ukazania koncepcji, czym miałby on być. Samym prymatem, jak i koncepcją jego sprawowania, nie będziemy się zajmować, zainteresowanych odsyłam do materiałów z XII Symposium syriacum.

2. Odwołania biblijne dotyczące prymatu. Argumentacja teologiczna Tymoteusza ma trzy podstawowe wymiary. Pierwszym z nich jest pochodzenie Chrystusa:

„chrześcijaństwo z nas [pochodzi], Chrystus ukazał się w ciele [od nas], Ten, który jest Bogiem ponad wszystkim, [...]. Jak pokazaliśmy, Chrystus objawił się w ciele z nas i z tego, co nasze: jeśli [więc jest] tak, że Chrystus ukazał się w ciele z Dawida, to Dawid był synem Abrahama, Abraham był z nas, z synów Orientu. Oczywiste jest więc i udowodnione, że Chrystus był w ciele z Orientu i był z synów Orientu. Źródło więc życia ${ }^{5}$ chrześcijańskiego z synów Orientu ukazuje się i wzeszło".

Założyciel religii jest z Orientu, Jego pierwsi uczniowie są ludźmi Orientu, do ludzi Orientu należy więc - zdaniem Tymoteusza - prymat. I nie chodzi tylko o Chrystusa i Apostołów. Jest tu obecne odwołanie do całej historii zbawienia. Abraham jest Aramejczykiem, jak i w większości pozostali chrześcijanie na terenie państwa kalifów, z rodu Abrahama jest też Chrystus. Wiara rodzi się w Oriencie, to jest szczególne miejsce spotkania Boga i człowieka. Pierwszeństwo w tym porządku należy do Chrystusa, a nie do jego sługi, Piotra. To pierwszeństwo od zawsze było związane z ludźmi Orientu, a więc i dziś do nich przynależy. Dowodzenie jest historyczne bez odwołania do poszczególnych fragmentów Pisma Świętego, natomiast ma na uwadze całą historię zbawienia pojętą jako objawienie się Boga. Zwróćmy uwagę na typologiczne podejście do relacjonowanej historii, która okazuje się zbiorem obrazów

\footnotetext{
${ }^{4}$ Bibliografia dotycząca Tymoteusza jest zawarta np. w: J. Żelazny, Tymoteusz I-prekursorem ekumenizmu?, w: Tymoteusz I, Listy I-VIII, tłum., oprac. tekstu syryjskiego i wstęp J. Żelazny, Kraków 2015, 16-28.

${ }^{5} \mathrm{~W}$ oryginale 1. mnoga.

${ }^{6}$ Timotheus I Patriarcha, Epistula 26 (Ad Māranzekā [episcopum] Nìnewēe), ed. O. Braun, CSCO 74, Scriptores Syri 30, Louvain 1953, 148, tłum. łacińskie O. Braun: Thimothei Patriarchae I Epistulae, I, CSCO 75, Scriptores Syri 31, Louvain 1953, 100, thum. własne.
} 
mających swoje odniesienie do rzeczywistości dziś. To nie jest alegoria, ale zapowiedź poprzez konkretne znaki, jakimi są fakty z życia Chrystusa czy jego przodków.

Kolejnym argumentem biblijnym za prymatem w Oriencie jest pierwszeństwo wiary w Chrystusa:

„Jeśli więc Rzym z powodu Piotra Apostoła jest uważany za pierwszy rangą i [jest] przywódca [innych Kościołów], o ileż słuszniejszym jest, aby [za taki uznano] Saliq - Ktezyfont z powodu Pana Piotra? Jeśli ranga pierwszeństwa i stopień [godności winny należeć] słusznie do tych, którzy przed wszystkimi wyznali wiarę w Chrystusa, to my, synowie Orientu, przed wszystkimi wyznaliśmy wiarę $\mathrm{w}$ Chrystusa i zamanifestowaliśmy naszą wiarę publicznie: i w dwunastu posłańcach ${ }^{8}$, którzy przez gwiazdę byli przyprowadzeni; i ponownie w darach tych, które Jemu ofiarowali: złocie dla Króla królów i Pana panów, kadzidle jako temu, który jest Bogiem ponad wszystkim, mirrze jako symbolu męki za wszystkich Jego człowieczeństwa".

Skoro wyznanie wiary w bóstwo Chrystusa stało się przyczyną ustanowienia prymatu Piotra, jest to tzw. „milczące założenie”, ponieważ choć passus jest polemiką z rzymską interpretacją fragmentu z Ewangelii według św. Mateusza 16, 16-19, odnoszącą się do roli Piotra w Kościele, to jednak w całym tekście nie ma wprost ani cytatu, ani odniesienia do tego ewangelicznego tekstu - pierwszeństwo i prymat jest dla wielu związane z wyznaniem wiary. I tu pojawia się kolejny przykład analizy historycznej ze swoiście pojętą zapowiedzią. Pierwsze wyznanie wiary w bóstwo Chrystusa, w Jego misję królewską i zbawczą mękę, miało miejsce - zdaniem Tymoteusza I - dużo wcześniej i było, zgodnie z danymi z Ewangelii, dziełem 12 magów, którzy w swoich darach: kadzidle, złocie i mirrze wyznali w Nowonarodzonym Boga i Króla, i zapowiedzieli mękę Jezusa. Magowie pochodzili z Orientu ${ }^{10}$, oni pierwsi - choć byli wyznawcami „dobrej religii” - wyznali w pełni wiarę w Boże Synostwo Jezusa, a więc prymat przynależy się poprzez ich wyznanie wiary i pierwszeństwo w tym wyznaniu chrześcijanom mieszkającym w Oriencie i będącym ich spadkobiercami. Wyznanie wiary Magów nie jest alegorią, ich dary oznaczają konkretne wartości, oni użyli języka symbolu, by wyrazić swoją wiarę i swoje oczekiwanie. Złoto, kadzidło i mirra są „słowami” w języku znaków, które mają określone znaczenie i ukazuja jak pogańscy przedstawiciele Orientu potrafili rozpoznać Zbawiciela.

Wreszcie Tymoteusz przywołuje kwestię sprawowanej władzy politycznej:

„synom Orientu należy się i piękno, i honor, i pierwszeństwo stolicy: czy to z powodu chwały regionu - królem wszystkich regionów jest Orient; czy z powodu

\footnotetext{
${ }^{7}$ Dosłownie: ,jesteśmy dającymi manifest naszej wiary”.

${ }^{8} \mathrm{~W}$ tradycji orientalnej mamy 12 magów przynoszących dary.

${ }^{9}$ Timotheus I Patriarcha, Epistula 26, CSCO 74, 149, CSCO 74, 101, thum. własne.

${ }^{10} \mathrm{~W}$ tradycji orientalnej było ich 12, por. B. Landau, Revelation of the Magi: The Lost Tale of the Wise Men's Journey to Bethlehem, New York 2010.
} 
tego, że koroną raju jest ukoronowany - raj zaś ziemski [jest] typem królestwa niebieskiego; czy z powodu korony królestwa ziemskiego - w Oriencie bowiem Nimrod [jako] pierwszy (por. Rdz 10, 8-12) założył koronę królewską"11.

Można powiedzieć, że patriarcha polemizuje w tym momencie $\mathrm{z}$ hierarchami bizantyńskimi, którzy swoje pretensje do pierwszeństwa wiązali z byciem w łączności z władzą obecnie sprawującą władzę w chrześcijańskim świecie.

W chwili, gdy Patriarcha Bagdadu pisał ten list do Maranzeka, biskupa Niniwy, dziś Mosulu, kalifat bagdadzki pod rządami Abbasydów przeżywał swój rozkwit i było to jedno z najpotężniejszych państw ówczesnego świata, rozciaggające się od Indii po Hiszpanię. Trudno było porównywać z nim będące w defensywie imperium bizantyńskie czy ówczesną Europę Karola Wielkiego. Jednak tego argumentu odwołania się do potęgi muzułmańskich władców państwa, w którym mieszkał i które było jego ojczyzną, patriarcha nie używa. Odwołuje się do historii zapisanej w Biblii. Jeśli więc w historii prymat rodzi się z władzy, to - jak zaznacza Tymoteusz - początek władzy królewskiej łączy się zgodnie z danymi Pisma Świętego z Mezopotamią, tu bowiem według Księgi Rodzaju Nimrod jako pierwszy przywdział władzę królewską. Jednocześnie biblijny Eden, będący obrazem przyszłego królestwa niebieskiego, też mieści się na Wschodzie, na terenie pomiędzy Eufratem i Tygrysem. Tu więc jest początek rodzaju ludzkiego i jego instytucji. Widać tu egzegezę literalną, w której Eden oznaczał konkretne miejsce na ziemi, ogród ziemski położony na terenie Krainy Dwóch Rzek. Jest to zgodne z tendencjami, które kazały widzieć w Biblii zapis historii zbawienia, a nie alegorycznego odniesienia do początków rodzaju ludzkiego czy mitycznego opowiadania thumaczącego obecność zła i grzechu w świecie. Eden jest jednocześnie typem królestwa, które próbujemy realizować $\mathrm{i}$ które będzie zrealizowane w czasach ostatecznych. To nie alegoria, pod którą się ukrywa inna rzeczywistość, ale zapowiedź poprzez wydarzenia, które są zwiastunem i obrazem nadchodzącego czasu.

Winniśmy pamiętać, że w teologii Orientu historia jest zawsze objawieniem Boga. I ta zamierzchła, i ta ewangeliczna, ale także i ta, której jesteśmy aktorami. Bóg nieustannie mówi do człowieka poprzez historię, poprzez to, co my na Zachodzie nazywamy znakami czasu. Jeśli odczytuję na nowo historię, to dlatego, że szukam tam nie tyle proroctw, co sytuacji analogicznych, w których - oceniając po owocach - mogę rozpoznać słuszne wybory. Uczę się per analogiam, a analogie znajduję w tym, co już było. Wraca jak refren Koheletowe nihil novi sub sole. Jednocześnie tak pojęta historia nie tylko ukazuje mi sytuacje typiczne (z których czerpię analogie), ale i dostarcza obrazów i symboli, czyli elementów składowych języka, którym muszę się posłużyć mówiąc o Bogu. Obraz od symbolu różni użytek, jaki nadaję konkretnym wyobrażeniom. Nie jest to arbitralna decyzja egzegety, ale zamierzenie głównego reżysera dramatu życia, czyli Boga.

\footnotetext{
${ }^{11}$ Timotheus I Patriarcha, Epistula 26, CSCO 74, 149, CSCO 75, 101, thum. własne.
} 
3. Sposób argumentacji. O wiele więcej o sposobie egzegezy mówi nam jednak argumentacja dotycząca ,pięciu”, wśród których jeden jest gwarantem jedności, i z którego wypływa reszta. Wyraźnie choć nie wprost argumentacja jest związana z idea pentarchii, jaka była przywoływana $\mathrm{w}$ dyskusjach między łaciśkimi i greckimi wyznawcami chrześcijaństwa. Nas interesuje jednak relektura historii, jak i sposób nagromadzenia obrazów, które przez analogię pozwolą na podjęcie dyskusji na temat prymatu w Kościele.

Patriarcha przywołuje trzy obrazy mające w sposób typologiczny uzasadniać jego tezę o jednym z pięciu, który jest gwarantem jedności:

„I jak źródło, które wychodziło z Edenu i nawadniało Raj, rozdzielone następnie na cztery części; i jedno źródło na cztery odnogi, [czyli] po podsumowaniu jest pięć części; i natura wody jedna jest w nich pięciu, zatem jakość i sposób jeden; albo jeśli chcesz tak: jak [Księga] Powtórzonego Prawa i apostoł Paweł, tamto więc jak te cztery księgi Prawa albo cztery Ewangelie; gdy zatem połączy się je, liczbę pięć wypełniają i udoskonalają"12.

Jako pierwszy pojawia się w jego dowodzeniu opis rzek płynących z raju. I tak jedna rozdziela się na cztery. Cztery rzeki płynące na obszar całej ziemi są więc tymi, które swoje wody biorą z tej jednej, wychodzącej z Edenu będącego zapowiedzią archetypem (głową typu) raju. Woda w czterech rzekach pochodzi $\mathrm{z}$ jednej, to ta jedna zawiera $\mathrm{w}$ sobie pozostałe. Typ dotyczy pięciu, z których jeden jest źródłem dla pozostałych. Innymi słowy, jeśli wiara jest wodą duszy, to bez względu na to, gdzie czerpię napój, pochodzi on z Raju. $\mathrm{Z}$ niego wypływają rzeki mające swój początek w tej jednej rajskiej rzece. Warto zauważyć, że list dotyczy kwestii ważności chrztu we wspólnotach nie pozostających w jedności z Patriarchą. Kluczem dyskusji i punktem spornym jest kwestia wiary, a więc pytanie, czy wiara przekazana na chrzcie jest życiodajną wodą. W tym kontekście pada jasna odpowiedź: tak, wiara (woda) jest ta sama w każdej rzece, choć im dalej od źródła (Edenu), tym bardziej jest narażona na zanieczyszczenie.

Drugi obraz pochodzi ze struktury Starego Testamentu, z Pentateuchu. Tymoteusz zauważa, że Księga Powtórzonego Prawa jest swoistym compendium pozostałych czterech. Innymi słowy, to co konieczne w ekonomii Prawa Mojżeszowego dla zbawienia i życia zgodnego z Przymierzem, zawiera się w tej jednej. Znowu mamy pięć z wyróżnionym jednym: cztery księgi, które zawierają się w piątej, i znowu kwestia dotyka tego, co jest istotą wiary Żydów - Tory.

Trzeci przykład dotyczy Nowego Testamentu. Patriarcha zauważa, że listy Apostoła Pawła są swoista piata Ewangeliq zawierającą pozostałe przemyślenia w świetle zmartwychwstania. Mamy więc pięć ewangelii, gdyż listy Pawłowe pełnią taką rolę jak Księga Powtórzonego Prawa w Pentateuchu czy też rzeka nawadniająca Eden w stosunku do pozostałych czterech rzek. Znowu

${ }^{12}$ Tamże, CSCO 74, 148, CSCO 75, 100, tłum. własne. 
obraz jest analogiczny. W strukturze przekazu jest pięć elementów, z których jeden jest podsumowaniem pozostałych.

Czy jest to alegoria? Nie. Tymoteusz nie twierdzi, że wydarzenia te niosa w sobie ukrytą treść. On zwraca tylko uwagę, dokonując analizy historycznej zarówno opisu raju, jak i struktury Starego i Nowego Testamentu, że w historii zbawienia spotykamy się z układem cztery plus jeden, w którym ten jeden staje się sumą pozostałych, on je zawiera i niesie w sobie materiał pozostałych czterech. W ten sam sposób należy, jego zdaniem, patrzeć na trony patriarchalne. Jest jeden, z którego wszystko wypływa, który sumuje w sobie pozostałe:

„Źródło więc życia ${ }^{13}$ chrześcijańskiego z synów Orientu ukazuje się i wzeszło, i od nas podzielone jest na cztery głowy, które cały raj Kościoła katolickiego nawadniają napojem Boga i duchowym królestwa niebieskiego. Jak jest powiedziane, pierwszeństwo w porządku przyczyny ma pierwsze źródło, które wyszło z Edenu, aby nawodnić Raj, później były cztery głowy, które z niego się oddzieliły, te z których pije cieleśnie cały świat" ${ }^{\prime 4}$.

Zaproponowana interpretacja nie doszukuje się ukrytego znaczenia, ale próbuje, przy użyciu typów i obrazów zaczerpniętych z Biblii opisać nową rzeczywistość, nowe zagadnienie, jakim jest kwestia prymatu w Kościele. W dokonanej już historii chce poszukać wzorców na zasadzie nihil novi sub sole, czyli zdaniem Patriarchy każdy wierzący powinien poprzez życie i działalność świętych lub poprzez dane Pisma odnaleźć odpowiedź na nurtujące go pytania. Jest to poszukiwanie analogii a nie ukrytej treści w słowach Biblii. W dalszej część musimy więc sobie odpowiedzieć na dwa kolejne zagadnienia. Skoro poszukujemy analogii, to konkretnie jak je możemy odnaleźć? Które analogie są ważniejsze? Kolejne zagadnienie, to jak te analogie możemy przenieść na życie codzienne?

W teologii orientalnej miejscem uprzywilejowanym, w którym mogę szukać analogii wiary jest Pismo Święte. Historia zbawienia, słowa i czyny postaci tam opisanych dostarczają nam tych obrazów, które są uprzywilejowane w rozumowaniu teologicznym. Kolejnym miejscem jest historia, która dla Semity jest zawsze czasem działania Boga, zapisem Jego obecności. Szczególnie widać to tam, gdzie historia potwierdza proroctwa zawarte w Piśmie Świętym. Tak thumaczy się odczytywanie opisu zniszczenia Jerozolimy zawartego w Wojnie żydowskiej Józefa Flawiusza podczas liturgii. Jezus zapowiada zniszczenie Miasta, a Józef Flawiusz, choć nie chrześcijanin, o tym opowiada. Wreszcie świat, jako stworzenie, jest pierwszym słowem, jakie Bóg skierował do człowieka. $Z$ tych trzech miejsc możemy poszukiwać obrazów do analogii wiary, w tej kolejności, bo taka jest ich waga.

Jak można te analogie przenosić? To zagadnienie jest o wiele trudniejsze i odpowiedź zmienia się u kolejnych autorów. Chodzi bowiem tutaj o wyczucie

\footnotetext{
${ }^{13} \mathrm{~W}$ oryginale 1. mnoga.

${ }^{14}$ Tamże, CSCO 74, 148-149, CSCO 75, 100, thum. własne.
} 
i znalezienie za każdym razem racji pozwalającej na połączenie między sobą różnych zjawisk.

4. Założenia egzegetyczno-teologiczne. Mówiąc o obrazach, które stają się symbolami i poprzez analogię ukazują nam inne wartości, dotykamy kolejnego zagadnienia, jakim jest rodzaj języka użytego w Liście. Jak zauważyła Uta Posekel w swoim wykładzie w ramach XII Symposium syriacum ${ }^{15}$, autorzy orientalni unikają definicji i rozróżnień, wolą posługiwać się obrazem w świadomy sposób nie do końca zdeterminowanym ${ }^{16}$. Dla człowieka wychowanego w kulturze grecko-rzymskiej precyzja była wartością samą w sobie, dla człowieka Orientu w rozważaniach dotyczących Boga była bluźnierstwem. Odwołując się do Hymnów o wierze św. Efrema wykazała, że tzw. brak precyzji w sformułowaniach Liry Ducha Świętego - jak nazywano edesseńskiego diakona - był świadomym wyborem teologicznym. Mówiąc kategoriami naszej teologii, my nie tyle możemy określić, czym Bóg jest, co opisać, gdzie Go nie ma, czyli wyznaczyć przestrzeń Jego obecności. To zaś prowadzi do użycia obrazu jako języka teologii. W tej konwencji można zrozumieć, dlaczego opisując prymat sięga Patriarcha Bagdadu do trzech obrazów zaczerpniętych z Pisma Świętego, a więc jak zauważyliśmy, uprzywilejowanego miejsca jeśli chodzi o obrazy w teologii. One pozwalają w przyjętej przez niego metodologii, określić fakt prymatu i jednocześnie pozwalają go umiejscowić w życiu Kościoła nie podając jego jurydycznego zakresu. Innymi słowy, szukając analogii Tymoteusz szuka typów i obrazów, ponieważ takim językiem symbolicznym posługuje się w dialogu z nami Bóg.

Kolejne zagadnienie dotyczy tego, jak odczytać znaczenie analogii. Przyjęło się uważać, że różnica w podejściu pomiędzy środowiskiem antiocheńskim a aleksandryjską szkołą jest nie tyle w technice egzegetycznej, co w podejściu do zagadnień chrystologicznych ${ }^{17}$. Tymczasem, aby ocenić i znaleźć potrzebne mu obrazy i typy Tymoteusz odwołuje się do lekcji dosłownej Biblii. Czy to oznacza, że zgodnie z tym, co przypisuje się szkole antiocheńskiej, pomija jej aspekt chrystologiczny, a więc nie szuka jak aleksandryjczycy Słowa obecnego w całej historii?

Pamiętajmy, że chrześcijanie orientalni mają inną koncepcję czasu. Dla nich historia będąca zawsze czasem zbawienia, jest czasem dialogu, czasem modlitwy. Słowem człowieka są wybory, bo podobieństwo między nami i Stwórcą zasadza się właśnie na wolności. Życie i to, co się wokół nas dzieje, są natomiast odpowiedzią Boga, czyli dialog pomiędzy Stwórcą i stworzeniem

${ }^{15}$ Akta XII Symposium syriacum będą opublikowane w tym roku w Rzymie w ramach serii „Orientalia Christiana Analecta”.

${ }^{16}$ Por. J.W. Żelazny, Język symbolu jako charakterystyczny wymiar teologii św. Efrema. Zarys problematyki, VoxP 30 (2010) t. 55, 799-808.

${ }^{17}$ Por. M. Simonetti, Lettera ole allegoria, uno contributo alla storia dell'esegesi patistica, Roma 1985. 
nie tylko trwa, ale jest bardziej zobiektyzowany, nie jest zamknięty wyłącznie do wypowiadanych słów. Wracając do analizowanego zagadnienia, Chrystus jest obecny w Starym Testamencie, ale nie jako „ukryta obecność za innymi postaciami", ale jako Ten, który odpowiada człowiekowi poprzez kolejne zapisane wydarzenia. Innymi słowy obecność Chrystusa to wydarzenia historyczne, które się rozgrywają, a nie alegoryczne wyjaśnienie kolejnych fragmentów! Tzw. ,znaki czasu” otrzymują inną interpretację i jest ona związana z nieustanną epifanią, jaka dokonuje się w świecie. Chrystus jest obecny poprzez odpowiedzi, jakich nam udziela w wydarzeniach życia, a nie poprzez alegorię. Czy mamy do czynienia z ukrytym sensem? Tak, na zasadzie specyficznej historiozofii, a więc koncepcji historii, w której świat jest sceną dramatu człowieka uczącego się wolności w obecności Boga. Wydarzenia nie oznaczają alegorycznie innej rzeczywistości, ale będąc tym, czym są, bez żadnego ukrytego znaczenia, ukazują wybory i decyzje Boga i człowieka, i poprzez analogię pozwalają innym dokonać własnych wyborów. Rzeki nie są alegorią relacji pięciu stolic, księgi Tory ani Ewangelie z Listami Pawła nie są alegorią pentarchii, ale wskazuja, że w przekazie wiary istotną rolę odgrywa pięć czynników, z których jeden jest niejako sumą pozostałych.

\section{$* * *$}

W interpretacji Pisma Świętego wśród chrześcijan Orientu, a więc w starożytnej egzegezie orientalnej, istotny jest sens historyczny, bo to historia objawia nam Jezusa. Jest On obecny - jak w myśli Aleksandryjczyków - w całym Piśmie Świętym, na wszystkich jego kartach, lecz nie za zasłoną poprzez alegorię, ale poprzez czas mający swoje własne miejsce w objawieniu Słowa. Użycie typów i obrazów w objaśnianiu zagadnień biblijnych jest związane z koncepcją języka teologicznego, w której obrazy i typy zapisane w Piśmie Świętym pełnią szczególne miejsce w naszym mówieniu o Bogu. Są tymi elementami, z których z definicji winno się kształtować dyskurs teologiczny. Egzegeza ta przypomina w niektórych elementach zarówno podejście antiocheńskie jak i aleksandryjskie, choć z uwagi na swoje założenia podstawowe i aksjomaty jest czymś zupełnie innym. W wielu swoich wymiarach jest bliska zwalczanego przez nią judaizmu, bo dużo czerpie ze spuścizny diaspory żydowskiej rozporoszonej na Bliskim i Środkowym Wschodzie. 


\section{BIBLICAL JUSTIFICATION \\ OF PRIMACY OF THE BISPHOP OF ORIENT ON THE BASIS \\ OF THE LETTERS OF TIMOTHY I, PATRIARCH OF BAGHDAD}

\section{(Summary)}

In the interpretation of the Bible among Christians of the Orient, i.e. in the ancient Oriental exegesis, the historical sense is relevant, as history reveals Jesus to us. He is present, as the School of Alexandria describes, in the entire Bible, on its every page, but He is not veiled by allegory - He is present through time, having its special place in the revelation of the Word. Using types and images to explain certain points in the Bible is related to the concept of theological language in which types and images inscribed in the Holy Bible play an important role in our way of talking about God. They are elements that, by definition, should form the theological discourse. Certain elements of this exegesis are similar to concepts both of the School of Antioch and that of Alexandria, although, from the point of view of its basic assumptions and axioms, it is completely different. In many aspects, it is close to Judaism against which it fights so intensely, as many of its concepts are inspired by the heritage of the Jewish Diaspora of the Middle East.

Key words: Timothy I; pentarchy; oriental egsegesis; image; typology; primacy.

Słowa kluczowe: Tymoteusz I; pentarchia; egzegeza orientalna; obraz; typologia; prymat.

\section{Bibliografia}

\section{Źródła}

Timotheus I Patriarcha, Epistulae, ed. O. Braun, I, CSCO 74, Scriptores Syri 30, Louvain 1953; tłum. łacińskie O. Braun: Thimothei Patriarchae I Epistulae, I, CSCO 75, Scriptores Syri 31, Louvain 1953.

\section{Opracowania}

Brock S., Una fontana inesauribile. La Bibbia nella tradizione siriaca, Roma 2008.

Chiala S., La perla dai molti riflessi, Qiqajon 2014.

Landau B., Revelation of the Magi: The Lost Tale of the Wise Men's Journey to Bethlehem, New York 2010.

Rompay L. van, The Christian Syriac Tradition of Interpretation, w: Hebrew Bible Old Testament. The History of Its Interpretation, ed. M. Saebo, vol. 1: From the Beginnings to the Middle Ages (Until 1300), part 1: Antiquity, Güttingen 1996, 612-641.

Rompay L. van, Development of Biblical Interpretation in The Syrian Churches of the Middle Ages, w: Hebrew Bible Old Testament. The History of Its Interpretation, ed. M. Saebo, vol. 1: From the Beginnings to the Middle Ages (Until 1300), part 2: The Middle Ages, Güttingen 2000, 559-577.

Simonetti M., Lettera o/e allegoria, uno contributo alla storia dell'esegesi patristica, Roma 1985. 
ŻELAZnY J.W., Język symbolu jako charakterystyczny wymiar teologii św. Efrema. Zarys problematyki, VoxP 30 (2010) t. 55, 799-808.

ŻElazny J., Tymoteusz I-prekursorem ekumenizmu?, w: Tymoteusz I, Listy I-VIII, thum., opr. tekstu syryjskiego i wstęp ks. J. Żelazny, Kraków 2015, 5-28. 